ROCZNIKI NAUK SPOŁECZNYCH

Tom 13(49), numer $2-2021$

DOI: https://doi.org/10.18290/rns21492.5

\title{
MOTYWY ZAŁOŻENIA RODZINY ORAZ WYCHOWANIE DZIECI W OPINII MIESZKAŃCÓW WOJEWÓDZTWA PODKARPACKIEGO I MAŁOPOLSKIEGO
}

\section{WPROWADZENIE}

Rodzina jest ceniona przez Polaków jako wartość społeczna o znaczeniu podstawowym. Wielu polskich obywateli stawia życie rodzinne bardzo wysoko w swym systemie wartości (CBOS, 2019a, 2020). Wartość ta tkwi głęboko w realizowanych wzorach życia rodzinnego (Tyszka, 2001). Duże znaczenie rodziny w życiu jednostki wynika z jej wyjątkowości, bowiem ,rodzina zawsze pozostaje społecznością pierwotną i dla człowieka ma największe znaczenie" (Dyczewski, 2003, s. 9). Rodzina zawiązuje się w bardzo specyficzny sposób, ma też swoją unikalną strukturę i pełni sobie właściwe funkcje (Dyczewski, 2005). Jest też środkiem przekazu obowiązujących w danym społeczeństwie norm, wzorców, wartości oraz stanowi o trwałości społeczeństwa (Adamski, 2002).

Rodzina nie jest jednak instytucją niezmienną. Dane Głównego Urzędu Statystycznego $(2014,2019)$ dostarczają istotnych informacji na temat stanu i zmian w strukturze rodzin oraz czasu i sposobów ich zawiązywania. Te zmiany nie muszą oznaczać rezygnacji z małżeństwa i rodziny. Mogą być związane z tzw. syndromem opóźniania zawierania małżeństw i rodzenia dzieci (Kwak, 2015). Jak zauważa J. Mariański (2012) zarówno zmiany strukturalne, jak i zmiany w świadomości społecznej dotyczące rodziny są raczej ewolucyjne. Polacy wciąż deklarują wysoki poziom zadowolenia z życia w rodzinie i wysoką rangę wartości emocjonalnych integrujących rodzinę jako wspólnotę. Należy także zaznaczyć, że cechą współczesnego społeczeństwa jest rozpowszechnienie się alternatywnych form życia małżeńsko-rodzinnego

Dr Magdalena Pokrzywa - adiunkt, Uniwersytet Rzeszowski, Instytut Nauk Socjologicznych; adres do korespondencji: al. Rejtana 16c, 35-959 Rzeszów; e-mail: mpokrzywa@ur.edu.pl; ORCID: https://orcid.org/0000-0002-1546-2270. 
oraz coraz większa ich społeczna akceptacja (Slany, 2008; Gizicka, 2008, 2013; CBOS, 2019b).

Celem artykułu jest przedstawienie motywów założenia rodziny (posiadania dzieci) oraz wskazanie wartości, podobieństw i różnic w wychowaniu w rodzinie prokreacji i pochodzenia. Artykuł bazuje na badaniach ilościowych oraz badaniach jakościowych przeprowadzonych z przedstawicielami gospodarstw domowych w województwie podkarpackim i małopolskim ${ }^{1}$. Badania ilościowe zrealizowano za pomocą techniki CAPI, czyli wywiadów bezpośrednich wspomaganych komputerowo. Natomiast w realizacji badania jakościowego użyto techniki indywidualnego wywiadu pogłębionego (IDI).

\section{RODZINA JAKO ŚRODOWISKO PROKREACJI, WYCHOWANIA ORAZ WARTOŚCI}

Rodzina jest jedną z najbardziej podstawowych instytucji, w której realizuje się proces reprodukcji biologicznej, społecznej i kulturowej (Poleszczuk, 2014). Można ją postrzegać jako fundamentalną ramę reprodukcji, gdyż to w niej rodzą się ludzie oraz odtwarzają dobra i symbole. Jest układem wiążącym małżeństwo i prokreację, miejscem socjalizacji i transmisji kultury (Giza-Poleszczuk, 2005). Rodzina pełni wiele funkcji, m.in. utrzymuje ciągłość biologiczną społeczeństwa, przekazuje dziedzictwo kulturowe następnym pokoleniom, zaspokaja potrzeby emocjonalne ich członków. Jedną z głównych funkcji rodziny jest funkcja prokreacyjna (określana także mianem biologicznej), którą można uznać za pierwszorzędną czy też istotną. Oznacza ona zaspokajanie potrzeby jednostki do posiadania potomstwa oraz reprodukcyjnych potrzeb społeczeństwa (Szczepański, 1963; Tyszka, 1974; Adamski, 2002). Jest to funkcja najbardziej pierwotna oraz uprzednia w stosunku do innych funkcji rodziny. Znajduje się ona u podstaw każdej rodziny w tym sensie, że bez pojawienia się dziecka trudno mówić o rodzinie (Szlendak, 2010; Gębka, 2011).

Należy zauważyć, że następują ciągłe zmiany w procesie zakładania rodzin: spadek skłonności do zawierania małżeństw, zwiększająca się liczba osób żyjących w związkach niesformalizowanych, opóźnianie decyzji prokreacyjnych,

\footnotetext{
${ }^{1}$ Prezentowane badania, przeprowadzone w 2019 r. w ramach projektu „Kondycja społeczno-gospodarcza rodzin w województwach podkarpackim i małopolskim ze szczególnym uwzględnianiem zjawiska depopulacji”, były współfinansowane z Funduszu Spójności - z Programu Operacyjnego Pomoc Techniczna na lata 2014-2020. Projekt badawczy był realizowany przez Województwo Podkarpackie, Województwo Małopolskie, Urząd Statystyczny w Rzeszowie oraz Uniwersytet Rzeszowski.
} 
ograniczanie liczby dzieci $\mathrm{w}$ rodzinie, a nawet rezygnacja $\mathrm{z}$ posiadania potomstwa (Kwak, 2005; Mynarska, 2020). W przeszłości reprodukcja była instynktem naturalnym, obowiązkiem religijnym i powinnością pozwalającą przetrwać gatunkowi. Obecnie pragnienie dziecka przestaje być niezmiennym wzorcem postępowania społecznego czy też uniwersalną potrzebą (Bieńko, 2015). Współczesny człowiek uczestniczenie w życiu rodzinnym zaczyna traktować jako jeden, z teoretycznie wielu możliwych, stylów życia i wyborów (Kaufmann, 2004). Posiadanie dziecka zmieniło także swój charakter z wartości praktycznej (np. „ręce do pracy”, zabezpieczenie rodziców na starość) na wartość autoteliczną (zaspokojenie indywidualnej potrzeby rodzicielstwa) (Gębka, 2011). Rodzenie i wychowanie potomstwa w większości społeczeństw wciąż stanowi kulturowo-społeczny skrypt kobiecego macierzyństwa (Bieńko, 2008). Decyzja o prokreacji jest jednak często odkładana na czas po zaspokojeniu innych potrzeb (np. wykształcenia, kariery, mieszkania, stabilizacji finansowej) (Gębka, 2011; Kwak, 2015). Wysokie aspiracje edukacyjne i zawodowe, zmiany mentalnościowe kobiet związane z samorealizacją i karierą zawodową, konkurencja na rynku pracy i trudna sytuacja mieszkaniowa, trudne do pogodzenia obowiązki zawodowe i rodzinne wywołują zmiany w postawach i zachowaniach prokreacyjnych współczesnych Polaków (Frątczak, 2002; Slany, 2008; Gizicka, 2009; Laszewska-Hellriegel, 2011; Kwak, 2015).

Zmniejszająca się liczba urodzeń oraz rosnąca liczba osób bezdzietnych skłania badaczy do zainteresowania się nie tylko wpływem różnych czynników na decyzję o posiadaniu dzieci (np. ekonomicznych), ale także samymi indywidualnymi motywami i pragnieniami związanymi z posiadaniem (lub nie) dzieci (Mynarska, Rytel, 2014). Kwak (2005) zauważa, że współczesna rodzina nie jest już wspólnotą spajaną przez obowiązek solidarności, lecz staje się raczej związkiem z wyboru, stowarzyszeniem jednostek. Kształt współczesnej rodziny jest efektem negocjacji i decyzji jednostek ją tworzących (Taranowicz, 2020). Moc lub słabość rodziny i małżeństwa obecnie tkwi bardziej w jednostkach ją tworzących niż jest wywołana przez czynniki zewnętrzne (Dyczewski, 1991-1992).

Rodzina jest nie tylko podstawową jednostką reprodukcji populacji (Marody, Giza-Poleszczuk, 2004), lecz jej wyjątkowe znaczenie jest związane z jej postrzeganiem jako najbardziej naturalnego i odpowiedniego dla rozwoju jednostek środowiska społecznego (Żurek, 2006). Rodzina (choć może zmieniać się jej rozumienie czy też pełnione funkcje) niezmiennie stanowi najważniejsze środowisko wychowawcze i socjalizacyjne, w którym przekazywane są wartości, normy i wzorce postępowania oraz kształtują się postawy (Boguszewski, 2015; 
Jóźwik, 2015; Kwak, 2015). Inne grupy społeczne czy instytucje, takie jak np. szkoła, grupy rówieśnicze, środki społecznej komunikacji, Kościół, uzupełniają jedynie wpływ rodziny na dziecko (Cęcelek, 2005). Rodzinę - zdaniem A. Żurek (2020) - można traktować jako pewnego rodzaju pas transmisyjny, dzięki któremu jest wzmacniany i promowany system aksjonormatywny, na którym opiera się funkcjonowanie społeczeństwa. Rodzice przekazują dzieciom wartości w sposób bezpośredni (poprzez zamierzone działania wychowawcze, np. modelowanie, identyfikacja itp.) lub pośredni (np. przez postawy rodzicielskie, zaspokajanie potrzeb psychicznych, atmosferę emocjonalną). Bardzo istotny jest system przekonań rodziców, który odgrywa znaczącą rolę w doborze działań wychowawczych, które z kolei przekładają się na rozwój zachowania dziecka oraz jego systemu przekonań (Elżanowska, 2012).

$\mathrm{Z}$ rodziny wynosimy pewnego rodzaju bagaż doświadczeń, wzory, które w późniejszym okresie dorosłości mogą być powielane, modyfikowane lub odrzucane. Rodzina pochodzenia odgrywa ważną rolę, gdyż tworząc rodzinę prokreacji, w mniej lub bardziej świadomy sposób odwołujemy się do relacji, jakie były w naszej rodzinie macierzystej. Jej funkcjonowanie ma duże znaczenie dla budowania własnej rodziny w dorosłości, bowiem prawidłowo ukształtowane wzory w rodzinie pochodzenia sprzyjają prawidłowemu funkcjonowaniu rodziny prokreacji (Kwak, 2015).

\section{METODY, TECHNIKI BADAŃ I DOBÓR PRÓBY}

Wyniki przytoczone $\mathrm{w}$ niniejszym artykule pochodzą z badania przeprowadzonego w ramach projektu „Kondycja społeczno-gospodarcza rodzin w województwach podkarpackim i małopolskim ze szczególnym uwzględnianiem zjawiska depopulacji”. Badanie zrealizowano za pomocą metod jakościowych i ilościowych. Badania jakościowe pozwalają na opis, interpretację oraz wyjaśnienie zjawisk społecznych z perspektywy ,wewnętrznej” poprzez analizę doświadczenia jednostek i grup (Flick, 2011) oraz zrozumienie zachowania jednostek, ich wartości, emocji, postaw, przekonań i opinii (Frankfort-Nachmias, Nachmias, 2001). W tego typu badaniach głos aktorów społecznych (badanych) powinien być mocno zaakcentowany w tekście poprzez cytaty wypowiedzi, które uprawomocniają naukowo i realistycznie analizę oraz rzetelnie przedstawiają badany teren (Kostera, 2003).

Badania jakościowe przeprowadzono za pomocą techniki indywidualnego wywiadu pogłębionego. Dobór wywiadów był zgodny z zasadą maksymalnego 
zróżnicowania przypadków, czyli polegał na poszukiwaniu wielu różniących się od siebie jednostek analizy (płeć, wiek, liczba i wiek posiadanych dzieci, typ rodziny), co umożliwiło identyfikację istotnych, wspólnych wzorów zjawisk, które ujawniają się, pomimo zróżnicowania przypadków (Miles, Huberman, 2000). Analizie poddano 60 wywiadów pogłębionych, przeprowadzonych z osobami, które miały dzieci (małoletnie lub pełnoletnie). W wywiadach tych wzięło udział 15 mężczyzn i 45 kobiet. Większość osób badanych żyła w związku małżeńskim (36) lub samotnie wychowywała dzieci (14). Rodziny zrekonstruowane tworzyło siedmiu badanych, zaś w związku nieformalnym wychowywało dzieci troje badanych.

Badania ilościowe zrealizowano za pomocą techniki wywiadów bezpośrednich wspomaganych komputerowo (CAPI). Wzięło w nim udział 3347 przedstawicieli gospodarstw domowych z województwa podkarpackiego i małopolskiego. Niemal $40 \%$ badanych stanowili mężczyźni. Około $23 \%$ respondentów miało mniej niż 36 lat, 24\% - to osoby w wieku 36-50 lat; badanych powyżej 60. roku życia było niemal 37\%. W większości przypadków badani (2430 osób) pełnili rolę ojca lub matki; 1572 respondentów miało dzieci powyżej 18. roku życia, zaś 858 - dzieci małoletnie.

\section{MOTYWY PROKREACYJNE BADANYCH}

Wszystkim badanym pełniącym rolę matki lub ojca $(N=2430)$ zadano pytanie o motywy posiadania dzieci. Zdecydowana większość (około $74 \% *^{2}$ ) wskazywała, że posiadanie dzieci było dla nich „naturalną koleją rzeczy”, która łączyła się z zawarciem związku małżeńskiego i wejściem w kolejny etap życia. Znaczna część respondentów (43\%*) deklarowała, że posiadanie dzieci było zaplanowaną decyzją, która została przedyskutowana ze współmałżonkiem czy partnerem. Około 13\%* badanych oświadczyło, że posiadanie dziecka było podyktowane ich wewnętrzną potrzebą, niecałe $10 \% *$ wskazało, że dzieci pojawiły się w sposób nieplanowany, natomiast mniej niż 4\%* przyznało, że zdecydowali się na dzieci za namową małżonka/małżonki lub innych członków rodziny. Nieznaczna część respondentów wśród wielu motywów posiadania dzieci wskazała na chęć przekazania dzieciom swojego dorobku $(3 \% *)$ oraz obawę przez samotnością w starszym wieku (2\%*). Motywy posiadania dzieci nie były zróżnicowane ze względu na płeć respondenta, ale różniły się w zależności od wieku badanych. Starsi rodzice (osoby

\footnotetext{
2 * Procenty nie sumują się do 100, gdyż badani mogli wybrać więcej niż jedną odpowiedź.
} 
w wieku 70 lat i więcej) częściej wskazywali, że posiadanie przez nich dzieci było naturalną koleją rzeczy $(80 \% *)$, niż młodsi rodzice w wieku 18-29 lat (67\%* wskazań na tę odpowiedź). Natomiast młodsi rodzice (18-44 lata), częściej niż starsi (70 i więcej lat), podkreślali, że posiadanie dzieci było ich wewnętrzną potrzebą, której spełnienie zostało zaplanowane i przedyskutowane ze współmałżonkiem lub współmałżonką.

Analiza wywiadów pogłębionych pozwala na wnikliwsze zrozumienie motywów posiadania dzieci. Badani, opisując decyzję o posiadaniu dzieci, bardzo często używali takich słów, jak „to normalne”, „to naturalny etap”, „zwykła kolej rzeczy”. Starsi rodzice podkreślali, że posiadanie dzieci było dla nich pewnym obowiązkiem społecznym i zobowiązaniem wobec współmałżonka, z którym się związali: „Pierwszy powód to obowiązek mieć następców, drugi to była miłość. Jeżeli bierze się ślub, to pierwszym celem było za mojej młodości poczęcie dzieci [...], to był jakby obowiązek społeczny w stosunku do społeczeństwa" (w58, mężczyzna, 82 lata, wdowiec, dorosłe dzieci). Dla starszych rozmówców posiadanie dzieci nie zawsze łączyło się z wyborem, przemyślaną decyzją, lecz było czymś oczywistym, zwłaszcza społecznie, gdy zawierało się związek małżeński. Dzieci były naturalnym następstwem zawarcia małżeństwa i badani podkreślali, że nie zastanawiali się, czy mieć dzieci, czy też nie: „Po prostu wychodzi się za mąż, to trzeba być w ciąży. Tak się kiedyś myślało i tak trzeba było, więc nad tym się nie zastanawiałam. Natomiast dzisiaj młodzi ludzie planują, bo już wiem, jak to wygląda z perspektywy moich dzieci" (w53, kobieta, 57 lat, małżonka z dorosłymi dziećmi). Starsi rodzice (mający już pełnoletnie dzieci) zauważali różnice w podejściu do posiadania dzieci przez ich potomstwo. W swoich wypowiedziach podkreślali, że ich dorosłe dzieci odkładają decyzji o rodzicielstwie, planują je na dalszym etapie życia po zrealizowaniu innych celów (np. ukończenie studiów, znalezienie satysfakcjonującej pracy itp.).

Dziecko coraz częściej jest postrzegane jako spełnienie osobistych dążeń rodziców, jako realizacja własnej potrzeby, czynnik własnego rozwoju. Takie postrzeganie dziecka i rodzicielstwa sprawia, że umieszczane są one w przestrzeni prywatnej, w pewien sposób „prywatyzowane” (Dyczewski, 2003). W wypowiedziach młodszych rodziców również podkreślano „,naturalność ich posiadania", jednak bardzo często badani wskazywali na potrzebę samorealizacji poprzez posiadanie dzieci, na wartość, jaką stanowi dla nich rodzina: „No, z powodu takiej samorealizacji, tak? Chęci posiadania potomstwa. Dostosowywałam gdzieś tam swoją sytuację na rynku pracy, żeby mieć tych dzieci ile mamy" (w03, kobieta 34 lat, mężatka, małe dzieci). Dzieci dla 
młodszych badanych były także impulsem do działania, sposobem spędzania czasu wolnego, zabezpieczeniem przed poczuciem samotności czy też wypełnieniem ,pustki”. Ich posiadanie zaspokajało potrzeby emocjonalne, dawało im poczucie bliskości z innymi, wyznaczało nowe odpowiedzialne role, stanowiło sens życia: „Rodzina dla mnie jest wartością. Uważam, że człowiek się realizuje w rodzinie, jako ojciec, jako mąż. Nie chciałem być sam. Dzieci zawsze dają taki bodziec, dają chęci do życia, do starania się, do pracy" (w50, mężczyzna, 54 lat, małżonek z dorastającymi dziećmi).

Posiadanie dzieci dla części badanych stanowiło zysk emocjonalny, w którym dzieci powodują wzrost wartości życia rodziców i są uznawane za element kształtujący cel ich życia (Laszewska-Hellriegel, 2011). W niektórych wypowiedziach można dostrzec także motywy ekonomiczne związane z zapewnieniem przez dzieci wsparcia na starość. Część badanych kobiet wskazywała także, że dla nich macierzyństwo wiązało się z poczuciem bycia „spełnioną" kobietą. Pełnienie roli matki było dla nich „oczywistością”. Podkreślały, że zwłaszcza dla kobiety rodzicielstwo wydaje się kluczowe i istotne z punktu widzenia pełnionych ról płciowych. Macierzyństwo stanowi odrębną (obok rodziny) wartość w świadomości kobiet (Frąckowiak, 2007).

Wypowiedzi niektórych badanych wskazują, że posiadanie dziecka nie zawsze jest takim samym pragnieniem dla obojga małżonków. Zarówno kobiety, jak i mężczyźni czasem zmuszeni są do pewnego rodzaju kompromisów w tym zakresie: „Mój mąż bardzo chciał mieć przynajmniej jedno dziecko [...]. Można powiedzieć, że pierwsze dziecko pojawiło się z miłości do mojego męża [...]. A drugie dziecko to była to po prostu klasyczna «wpadka»" (w41, kobieta, 45 lat, małżonka z małymi i dorastającymi dziećmi); „Ja mogę powiedzieć, że to głównie mnie na tym zależało [...], dlatego to tak długo trwało, bo mąż musiał się po prostu zdecydować" (w57, kobieta 31 lat, spodziewająca się dziecka, rodzina zrekonstruowana).

Jednak sama chęć posiadania dziecka, pragnienie założenia rodziny nie jest elementem wystarczającym do prokreacji. W bardzo wielu wypowiedziach pojawiały się wskazania nie tylko motywów posiadania dzieci, lecz także warunków, w których zdecydowano się na pierwsze bądź kolejne dziecko. Warunki te były związane przede wszystkim z sytuacją finansową i mieszkaniową, poczuciem bezpieczeństwa ekonomicznego oraz ustabilizowaną sytuacją zawodową kobiet (np. uzyskanie umowy o pracę na czas nieokreślony): „Na kolejne dzieci, to w sumie zdecydowaliśmy się dopiero jak ja dostałam tę umowę na czas nieokreślony, czyli praktycznie tam po pięciu latach były jakieś tam starania [...] trzeba było to bardziej rozważyć, czy po prostu sobie 
damy radę z ratą kredytu i z kolejnym dzieckiem, prawda?” (w22, kobieta 33 lat, małżonka, troje dzieci). W przypadku odkładania decyzji o posiadaniu pierwszego lub kolejnego dziecka z przyczyn materialnych trudno jest jednoznacznie określić np. minimalny zasób posiadanych dóbr materialnych bądź środków finansowych, który pozwalałby na podjęcie decyzji o prokreacji. Ocena sytuacji w większości przypadków ma charakter bardzo subiektywny (Gębka, 2011).

Część badanych kobiet podkreślała, że decyzja o posiadaniu dziecka zapadła dopiero w momencie poznania odpowiedniego partnera: „Jesteśmy po rozwodach, wyszliśmy z innych związków. Jesteśmy rodziną patchworkową [...]. Powiem tak: znalazłam odpowiedniego partnera. Myślę, że do 32. roku życia nie zakładałam posiadania dzieci. Naprawdę skupiałam się na karierze zawodowej, na tym, co wtedy robiłam. Chyba dopiero spotkanie mojego obecnego męża spowodowało, że zdecydowałam się na dzieci" (w48, kobieta, 39 lat, rodzina zrekonstruowana $\mathrm{z}$ trojgiem dzieci). Jak wskazują wyniki innych badań, ów brak odpowiedniego i stałego partnera, który w opinii kobiet byłby odpowiednim kandydatem na ojca, może odgrywać dużą rolę w opóźnianiu decyzji o urodzeniu dziecka lub nawet rezygnacji z prokreacji (Söderberg i in., 2015).

Niektórzy badani tworzyli rodzinę przez więź prawną, adopcyjną, a nie wspólne pokrewieństwo. Po nieudanym staraniu się o posiadanie biologicznych dzieci zdecydowali się na adopcję: „Cała radość w dzieciach [...]. Po prostu stwierdziliśmy: stało się, co się stało. No nie możemy mieć własnych dzieci, więc nie cudowaliśmy żadnych tam in vitro itd., tylko zdecydowaliśmy się na adopcję" (w43, kobieta, 49 lat, rodzina $z$ dwojgiem adoptowanych dzieci). Badani podkreślali, że proces adopcji był długotrwały i łączył się z wieloma przeszkodami oraz różnymi emocjami. Jak jednak wskazywali, mimo tych przeszkód oraz pewnych problemów po akcie adopcji, decyzja o poszerzeniu rodziny była najlepszą, na jaką mogli się zdecydować.

\section{WARTOŚCI ORAZ RÓŻNICE W WYCHOWANIU W RODZINIE PROKREACJI I POCHODZENIA}

Rozmówców mających dzieci poproszono o określenie wartości, jakimi się kierują lub kierowali w ich wychowaniu, oraz o to, jakie wzorce postępowania starają się przekazywać swoim potomkom. Najczęściej wymienianymi wartościami były uczciwość, prawdomówność, szczerość. Te elementy były wskazywane jako fundament relacji rodzinnych i zasady, które badani chcieli 
przekazać swoim dzieciom. Uczciwość dotyczyła zarówno relacji rodzinnych, jak i interakcji z innymi osobami spoza rodzinny (badani podkreślali, że uczyli dzieci, że nie należy nikogo oszukiwać, kłamać, wykorzystywać, okradać itp.). Bardzo często wymienianymi wartościami były także szacunek dla drugiego człowieka (w tym znaczny nacisk kładziono na okazywanie szacunku starszym osobom), wrażliwość na uczucia innych, akceptacja innych osób, bezinteresowna pomoc, staranie się, by być dobrym człowiekiem, niekrzywdzenie innych: „Myślę, że przede wszystkim to musi być szacunek, zrozumienie drugiego człowieka i też po prostu taka otwartość. No to, co też mówi Pismo Święte, żeby po prostu traktować dobrze drugiego człowieka i starać mu się pomóc" (w57, kobieta, 31 lat, rodzina zrekonstruowana z małymi i dorosłymi dziećmi). Jak wskazuje Tyszka (2001), rodziny polskie znajdowały się przez wiele wieków w kręgu silnego oddziaływania tradycji religijnych (zwłaszcza katolickich), które ujawniają się w normach i wzorcach życia rodzinnego, moralności i obyczajowości rodzinnej. Wielu badanych, wskazując na wartości, jakie starali się lub starają przekazywać dzieciom, odnosiło się do dekalogu, wartości chrześcijańskich, podkreślało ważność religii i życia zgodnie w jej zasadami: „No to: prawda, uczciwość. Staramy się wychować dzieci według Dziesięciu Przykazań, tak można najkrócej powiedzieć. Czyli tak, jak naucza kościół. Staramy się, żeby dzieci były uczciwe, żeby przede wszystkim innym jakiejś krzywdy nie wyrządzały" (w50, kobieta, 54 lata, małżonka $\mathrm{z}$ dorastającymi dziećmi). Znaczenie religii $\mathrm{w}$ życiu rodzin jest związane z uwarunkowaniami kulturowymi i strukturalnymi. Rodzina jest pierwszym ośrodkiem kształtowania postaw religijnych oraz wpisuje te wartości w biografie poszczególnych członków rodziny (Świątkiewicz, 1992).

Bardzo często podkreślaną wartością była sama rodzina i pozytywne relacje rodzinne. Badani deklarowali, że bardzo zależy im, by ich dzieci potrafiły z jednej strony docenić wartość, jaką jest sama rodzina, jej wsparcie, więzi rodzinne, z drugiej zaś umiały kształtować relacje np. z rodzeństwem, osobami spokrewnionymi, by dawały one im satysfakcję, poczucie bezpieczeństwa i wsparcia: „Miłość, którą chcemy wpajać od młodych lat. Też miłość do rodziny. Rodzina przede wszystkim" (w45, kobieta, 45 lat, rodzina wielopokoleniowa). Część rodziców podkreślała, że stara się w wychowaniu dzieci kłaść nacisk na ich indywidualny rozwój, wzbudzenie w nich zainteresowań, wzmacnianie i wspieranie ich pasji, na uzyskanie odpowiedniej edukacji i samodzielności, budowanie poczucia ich własnej wartości i sprawczości: „Ważne jest, by dać im przestrzeń do tego, żeby po prostu byli sobą. Ja staram się, żeby one realizowały swoje pasje, swoje zainteresowania [...] każde dziecko, żeby było 
rozwinięte emocjonalnie czy społecznie, żeby miało dobry kontakt z innymi ludźmi” (w08, mężczyzna, 49 lat, rodzina zrekonstruowana, z małym dzieckiem oraz z dziećmi studiującymi i samodzielnymi).

Rodzicielstwo nie realizuje się w społecznej próżni. Podlega ono zmianom społeczno-kulturowym, cywilizacyjnym i demograficznym. Jest zadaniem niemal całożyciowym i wieloaspektowym, związanym z koniecznością radzenia sobie z problemami o różnej naturze, np. społecznej, poznawczej, emocjonalnej, religijnej, moralnej (Opozda, 2007). Relacje rodziców z dziećmi ze względu na zmieniające się otoczenie społeczne są wciąż na nowo definiowane, redefiniowane oraz wyrażane podczas ciągłych interakcji (Bieńko, 2020). Wielu badanych rodziców wskazuje, że ich sposób wychowania dzieci różni się od tego, w jaki oni sami byli wychowywani. Bardzo często w wypowiedziach, zwłaszcza starszych rodziców, pojawia się odniesienie do licznych obowiązków, które musieli wypełniać jako dzieci w swoich rodzinach pochodzenia (np. w dzieciństwie pracowali bardzo dużo na roli, opiekowali się trzodą, byli odpowiedzialni za opiekę nad młodszym rodzeństwem, zarabiali na swoje utrzymanie przed osiągnięciem pełnoletności). Większość rodziców podkreśla, że obecnie głównym obowiązkiem ich dzieci jest edukacja oraz ewentualna pomoc przy codziennych czynnościach domowych. Ich zdaniem obecnie dzieci mają zdecydowanie mniej obowiązków, więcej czasu wolnego i większą swobodę w wyborze sposobu jego spędzania. Wielu badanych twierdziło też, że ich rodzina pochodzenia zmagała się z problemami finansowymi, doświadczała ubóstwa. Sytuacja ta dotyczyła przede wszystkim osób, które wychowały się w rodzinie monoparenalnej, wielodzietnej lub dysfunkcjonalnej. Część rozmówców wspominała także o tym, że nie miała pozytywnych wzorców wychowania w swojej rodzinie pochodzenia. Wskazywała, że w rodzinie występowała przemoc fizyczna lub psychiczna, uzależnienie od alkoholu, niektórzy badani trafili nawet do placówek opiekuńczo-wychowawczych. Z tego względu nieliczni rozmówcy nie utrzymują kontaktów ze swoimi rodzicami. Podkreślają oni, że w przypadku wychowania swoich dzieci musieli sami przemyśleć jego zasady oraz nauczyć się budowania relacji z bliskimi: „Ja pochodzę z nieco dysfunkcyjnego domu, gdzie matka z ojcem się niezbyt dogadywali [...]. Właściwie u mnie o wszystkim decydował ojciec. Po prostu nie miał nawyku pytać się matki, a co dopiero dzieci, prawda? Panowała u nas przemoc psychiczna. W mniejszym stopniu przemoc fizyczna, ale też była obecna. Nie mam dobrego kontaktu z rodzicami do tej pory. Nie nawiązaliśmy żadnych więzi” (w41, kobieta, 45 lat, małżonka z małymi i dorastającymi dziećmi). Wielu rozmówców podkreślało, że w rodzinie pochodzenia rodzice 
nie liczyli się z ich zdaniem, nie pytali ich o zdanie nawet w przypadku podejmowania decyzji, które dotyczyły ich samych. Ci badani wskazywali, że kwestia decyzyjności dzieci i podmiotowego ich traktowania jest elementem, który bardzo różnicuje sposób wychowania przejawiany przez ich rodziców oraz przez nich samych. Bieńko (2020) zauważa, że obecnie dziecko staje się aktorem społecznym w rodzinie, równie ważnym jak dorosły. Współczesna rodzina zostaje podporządkowana dziecku, które jest w niej centralną postacią, wartością autoteliczną.

Rozmówcy podkreślali, że starają się rozmawiać ze swoimi dziećmi, poświęcać im więcej czasu, pytają ich o zdanie i się z nim liczą, dają większą swobodę, biorą pod uwagę ich odczucia, starają się budować w nich pozytywny obraz swojej osoby i poczucie własnej wartości: „Nigdy nie decydowałam o sobie. Było mi narzucane to, w co się mam ubrać i jak ma wyglądać mój pokój. Nie mogłam tutaj w żaden sposób decydować, dlatego się szybko wyprowadziłam z domu [...]. Wiem też, że moi rodzice po prostu byli nauczeni, że w ten sposób wychowuje się dziecko. Natomiast ja chciałam, żeby moje dzieci miały to, czego mi brakowało, czyli żeby słyszały, że są wspaniałe, że są kochane, że dużo potrafią. Właśnie, żeby wiedziały, że mogą decydować od samego początku o sobie, o swoim życiu" (w48, kobieta, 39 lat, rodzina zrekonstruowana $\mathrm{z}$ trojgiem dzieci). Badani ci jednak wskazywali, że poszukiwanie innego, odmiennego stylu wychowania nie jest dla nich łatwe ze względu na negatywne wzorce, które musieli sobie uświadomić i starać się zmienić. Część badanych w tym celu poszukiwała informacji o wychowaniu dzieci, czytała odpowiednią literaturę, szukała pomocy psychologicznej, by poradzić sobie ze swoją przeszłością i uczuciami, zastanawiała się, jak odpowiednio zbudować relacje $\mathrm{z}$ najbliższymi. Znaczna różnica w stylu wychowania dotyczyła także tzw. klapsów. Rozmówcy podkreślali, że w wielu przypadkach ich rodzice stosowali „klapsy” jako narzędzie wychowawcze. Co ciekawe, do stosowania kar cielesnych przyznawała się część starszych badanych rodziców. Wskazywali oni, że okazjonalnie dyscyplinowali swoje dzieci za pomocą „klapsa”. Młodsi rodzice deklarowali, że takich kar nie stosują, natomiast czasem podkreślali, że ich rodzice stosowali kary fizyczne. To właśnie stosowanie kar fizycznych i włączanie dzieci w procesy decyzyjne wydają się kluczowymi elementami różnicującymi style wychowania w rodzinie prokreacji i w rodzinie pochodzenia. Różnice w wychowaniu dzieci między tymi rodzinami można postrzegać jako pierwszy etap dokonującej się zmiany pokoleń. Owe różnice mogą przybierać różne postacie: od jawnej kontestacji świata rodziców i jego systemu wartości przez dorosłe dzieci, 
poprzez przejawy młodzieńczego kwestionowania, eksperymentowania i pewnego rodzaju buntu w procesie kształtowania tożsamości społecznej jednostki, aż po harmonijną egzystencję pokoleń charakteryzującą się znaczną unifikacją ich systemów aksjonormatywnych (Wrzesień, 2001).

Część badanych podkreślała, że stara się wychować swoje dzieci podobnie jak sami zostali wychowani przez swoich rodziców. Takie stwierdzenia najczęściej pojawiały się w wypowiedziach młodszych osób. Wskazywali oni często, że wychowywali się w zgodnej, szczęśliwej rodzinie i chcieliby zapewnić podobne środowisko wychowawcze swoim dzieciom: „Ja mam takie doświadczenie, że moi rodzice zawsze liczyli się gdzieś z moim głosem. Wiadomo, że ten głos dziecka i wpływ na jakąś tam rzeczywistość jest dużo mniejszy niż osób dorosłych. Natomiast jeżeli chciałem się rozwijać w jakimś kierunku, i nawet jeżeli rodzicom nie do końca się to podobało, to oni mnie wspierali, bo widzieli, że dla mnie było to ważne [...]. Ja chcę tak samo wychować dzieci" (w15, mężczyzna, 38 lat, małżonek z małym dzieckiem).

W większości wypowiedzi jednak można zauważyć, że badani rodzice podkreślają zmiany społeczne, jakie nastąpiły w kwestiach związanych z wychowaniem. Wskazywano na większe zwrócenie uwagi na potrzeby dzieci, ich odczucia, podmiotowość. Zdaniem badanych głównym punktem rodziny stają się obecnie dzieci, ich dobro, potrzeby, rozwój. Dzieci mają także mniej obowiązków, więcej dóbr materialnych i możliwości (np. zabawek, zajęć dodatkowych rozwijających ich zainteresowania, możliwości sposobu spędzania czasu wolnego). Rodzice zauważali, że ich dzieci wychowują się też w innej rzeczywistości społecznej, niż wychowywali się oni sami. Kluczową kwestię odgrywają tu nowoczesne technologie (ich powszechność, rola w budowaniu relacji, sposobie komunikacji z innymi). Jak zauważa Żurek (2020), w domu, który jest najważniejszą przestrzenią dla członków rodziny, przeplatają się dwa porządki: zbiorowy i jednostkowy. Porządek jednostkowy, mimo wspólnotowego charakteru rodziny, zaczyna dominować. Jego skutkiem stają się coraz częstsze sytuacje, w których członkowie rodziny przebywają w swoich subświatach, w których nie przebywają inni członkowie rodziny. Szczególne znaczenie w tym aspekcie mają tu nowoczesne technologie komunikacyjne. Dzieci żyjące w XXI wieku są określane mianem „,cyfrowych tubylców”, nowe media są dla nich naturalnym środowiskiem egzystowania (Bieńko, 2020). Badani rodzice wskazywali także na nowe problemy, jakie mogą doświadczać ich dzieci, w porównaniu z czasami ich dorastania. Są one związane przede wszystkim z trudnościami w budowaniu relacji z rówieśnikami, konsumpcyjnym społeczeństwem, w którym wartość dziecka dla jego rówieśników jest 
wyznaczana przez dobra materialne, które posiada. Jak zauważa Bieńko (2020), obecnie dzieci znajdują się w centrum wydarzeń społecznych i są bez przerwy wystawione na „konsumpcyjne” kryteria wartościowania. Niepokój badanych rodziców wzbudza także powszechność i łatwy dostęp do substancji psychoaktywnych.

\section{WNIOSKI}

Motywy prokreacyjne badanych są związane z ich postrzeganiem dzieci jako „naturalnej kolei rzeczy”, która jest elementem osiągnięcia określonego etapu w życiu. Można dostrzec pewne różnice w aspekcie motywów posiadania dzieci. O ile starsi rodzice wskazywali, że posiadanie potomstwa było obowiązkiem społecznym, pewnego rodzaju oczekiwaniem społecznym, którego spełnienie traktowano jako naturalną konsekwencję zawartego małżeństwa, o tyle młodsi rodzice podkreślali wartość posiadania dzieci w aspekcie dopełnienia ich życia, świadomego wyboru i decyzji oraz samorealizacji. Badani dostrzegali różnice $w$ zachowaniach prokreacyjnych między pokoleniami. Starsi rodzice stwierdzali, że ich dorosłe dzieci odkładają decyzję o rodzicielstwie. Młodsi rodzice częściej zwracali uwagę na warunki, w jakich zdecydowali się na pierwsze lub kolejne dziecko (np. stabilna sytuacja finansowa, zawodowa, mieszkaniowa). Rodzicielstwo dla młodszych badanych wydaje się indywidualną, prywatną decyzją. Decyzje prokreacyjne są także związane $\mathrm{z}$ kompromisami w związku intymnym

Najważniejszymi wartościami, które chcą przekazać swoim dzieciom badani rodzice, są uczciwość, prawdomówność, szczerość, szacunek dla innych, wrażliwość na uczucia innych, wartości chrześcijańskie związane z dekalogiem. Jak podkreślali, starają się rozmawiać ze swoimi dziećmi i włączać je w procesy decyzyjne. Na podmiotowe traktowanie dzieci szczególną uwagę zwracało wielu badanych. Wskazywali oni, że w rodzinie pochodzenia ich odczucia i opinie często były traktowane jako nieistotne, więc dla nich te kwestie w wychowywaniu własnych dzieci są bardzo ważne. Część rozmówców starała się wychowywać swoje dzieci podobnie, jak sami zostali wychowani. Zwracali oni jednak uwagę na zmianę otoczenia społecznego: pojawienie się nowych mediów i środków komunikacji oraz problemów związanych z konsumpcyjnym społeczeństwem, a także powszechniejszym dostępem do środków psychoaktywnych. 


\section{BIBLIOGRAFIA}

Adamski F. (2002), Rodzina. Wymiar społeczno-kulturowy, Kraków: Wydawnictwo Uniwersytetu Jagiellońskiego.

Bieńko M. (2008), Kulturowo-społeczne skrypty kobiecego macierzyństwa, [w:] A. Kwak, (red.), Rodzicielstwo między domem, prawem, stużbami społecznymi, Warszawa: APS, s. 41-63.

Bieńko M. (2015), Perfekcyjna matka oraz bachor w poradnikach i bezradnikach wspótczesnej pop kultury, [w:] I. Taranowicz, S. Grotowska (red.), Rodzina wobec wyzwań wspótczesności. Wybrane problemy, Wrocław: Oficyna Wydawnicza Arboretum, s. 91-106.

Bieńko M. (2020), Wyrafinowane projekty, dawniej znane pod nazwa dzieci, [w:] M. Bieńko, M. Rosochacka-Gmitrzak, E. Wideł (red.), Obrazy życia rodzinnego i intymności. Ksiązka dedykowana Profesor Annie Kwak, Warszawa: Wydawnictwo Uniwersytetu Warszawskiego, s. 167-182.

Boguszewski R. (2015), Wspótczesne znaczenie i rozumienie rodziny w Polsce, Zeszyty Naukowe KUL, nr 58(4), s. 127-148.

CBOS (2019a), Rodzina - jej znaczenie i rozumienie, Komunikat z badań nr 22, www.cbos.pl/SPI SKOM.POL/2019/K_022_19.PDF [dostęp: 15.04.2021].

CBOS (2019b), Alternatywne modele życia rodzinnego w ocenie społecznej, Komunikat z badań nr 42, www.cbos.pl/SPISKOM.POL/2019/K_042_19.PDF [dostęp: 17.04.2021].

CBOS (2020), Wartości w czasach zarazy, Komunikat z badań nr 160, https://www.cbos.pl/SPIS KOM.POL/2020/K_160_20.PDF [dostęp: 17.04.2021].

Cęcelek G. (2005), Rodzina - jej przemiany oraz zagrożenia i problemy wychowawcze, Mazowieckie Studia Humanistyczne, nr 11(1-2), s. 239-249.

Dyczewski L. (1991-1992), Rodzina i społeczeństwo, Rocznik Nauk Społecznych, nr 19-20(1), s. 83-97.

Dyczewski L. (2003), Rodzina twórca i przekazicielem kultury, Lublin: Towarzystwo Naukowe KUL.

Dyczewski L. (2005), Więź rodzinna a media elektroniczne, Ruch Prawniczy, Ekonomiczny i Socjologiczny, z. 67(1), s. 225-242.

Elżanowska H. (2012), Międzypokoleniowa transmisja wartości w rodzinie, [w:] O. Gorbaniuk, B. Kostrubiec-Wojtachnio, D. Musiał, M. Wiechetek (red.), Studia z Psychologii w KUL, t. 18, Lublin: Wydawnictwo KUL, s. 97-114.

Flick U. (2011), Jakość w badaniach jakościowych, Warszawa: Wydawnictwo Naukowe PWN.

Frankfort-Nachmias C., Nachmias D. (2001), Metody badawcze w naukach spotecznych, Poznań: Zysk i S-ka.

Frąckowiak M. (2007), Rodzina jako wartość w świadomości wspótczesnych Polek, Roczniki Socjologii Rodziny, t. 18, s. 15-38.

Frątczak E. (2002), Postawy i zachowania rodzinne oraz prokreacyjne młodego i średniego pokolenia kobiet i mężczyzn w Polsce, [w:] E. Frątczak, E. Orzełek (red.), Sytuacja demograficzna Polski. Raport 2001, Warszawa: Rządowa Rada Ludnościowa, s. 161-173.

Gębka M. (2011), Funkcja prokreacyjna na rozdrożu?, Roczniki Socjologii Rodziny, t. 21, s. 37-55.

Giza-Poleszczuk A. (2005), Rodzina a system spoteczny. Reprodukcja i kooperacja w perspektywie interdyscyplinarnej, Warszawa: Wydawnictwo Uniwersytetu Warszawskiego.

Gizicka D. (2008), Kohabitacja jako alternatywna forma życia rodzinnego, Roczniki Nauk Społecznych, nr 36(1), s. 197-216. 
Gizicka D. (2009), Praca zawodowa kobiety a jej miejsce w rodzinie, [w:] M. Szyszka (red.), Społeczeństwo, przestrzeń, rodzina. Księga jubileuszowa dedykowana Profesorowi Piotrowi Kryczce, Lublin: Wydawnictwo KUL, s. 317-330.

Gizicka D. (2013), Kohabitacja w Polsce w kontekście zmian postrzegania rodziny, Roczniki Nauk Społecznych, nr 5(41)(4), s. 67-82.

GUS (2014), Gospodarstwa domowe i rodziny. Charakterystyka demograficzna. Narodowy Spis Powszechny Ludności i Mieszkań 2011, Warszawa: Zakład Wydawnictw Statystycznych.

GUS (2019), Sytuacja demograficzna Polski do 2018 r. Tworzenie i rozpad rodzin, Warszawa: Departament Badań Demograficznych GUS.

Jóźwik M. (2015), Międzypokoleniowy przekaz wartości w rodzinie, Wrocławski Przegląd Teologiczny, nr 23(1), s. 139-154.

Kaufmann J.C. (2004), Ego. Socjologia jednostki. Inna wizja człowieka i konstrukcji podmiotu, Warszawa: Oficyna Naukowa.

Kostera M. (2003), Antropologia organizacji. Metodologia badań terenowych, Warszawa: Wydawnictwo Naukowe PWN.

Kwak A. (2005), Rodzina w dobie przemian. Matżeństwo i kohabitacja, Warszawa: Wydawnictwo Akademickie Żak.

Kwak A. (2015), Wspótczesna rodzina - czy tylko problem struktury zewnętrznej?, [w:] I. Taranowicz, S. Grotowska (red.), Rodzina wobec wyzwań wspótczesności. Wybrane problemy, Wrocław: Oficyna Wydawnicza Arboretum, s. 11-26.

Laszewska-Hellriegel M. (2011), Czynniki majace wptyw na podejmowanie decyzji o posiadaniu dziecka przez potencjalnych rodziców. Analiza pieniężnych i niepieniężnych kosztów oraz zysków z posiadania dziecka, Roczniki Socjologii Rodziny, t. 21, s. 57-77.

Mariański J. (2012), Matżeństwo i rodzina $w$ świadomości młodzieży maturalnej - stabilność i zmiana, Toruń: Wydawnictwo Adam Marszałek.

Marody M., Giza-Poleszczuk A. (2004), Przemiany więzi spotecznych, Warszawa: Wydawnictwo Naukowe Scholar.

Miles M.B., Huberman A.M. (2000), Analiza danych jakościowych, Białystok: Trans Humana.

Mynarska M. (2020), Korzyści płynące z rodzicielstwa w perspektywie biegu życia, [w:] M. Bieńko, M. Rosochacka-Gmitrzak, E. Wideł (red.), Obrazy życia rodzinnego i intymności. Książka dedykowana Profesor Annie Kwak, Warszawa: Wydawnictwo Uniwersytetu Warszawskiego, s. 153-166.

Mynarska M., Rytel J. (2014), Pomiar motywacji do posiadania dzieci wśród osób bezdzietnych. Polska adaptacja kwestionariusza motywów rodzicielskich, Polskie Forum Psychologiczne, nr 19(4), s. 522-543.

Opozda D. (2007), Wprowadzenie, [w:] D. Opozda (red.), Rodzicielstwo. Wybrane zagadnienia kontekstów edukacyjnych $w$ sytuacji dezorganizacji rodziny i możliwości wspomagania rodziców, Lublin: Wydawnictwo Episteme, s. 9-10.

Poleszczuk J. (2014), Rodzina - wspólnota konfliktowych interesów, Pogranicze. Studia Społeczne, t. 24 , s. 13-27.

Slany K. (2008), Alternatywne formy życia małżeńsko-rodzinnego w ponowoczesnym świecie, Kraków: Zakład Wydawniczy „Nomos”.

Söderberg M., Christensson K., Lundgren I., Hildingsson I. (2015), Women's attitudes towards fertility and childbearing - A study based on a national sample of Swedish women validating the Attitudes to Fertility and Childbearing Scale (AFCS), Sexual \& Reproductive Healthcare, nr 6(2), s. 54-58. 
Szczepański J. (1963), Elementarne pojęcia socjologii, Warszawa: PWN.

Szlendak T. (2010), Socjologia rodziny. Ewolucja, historia, zróżnicowanie, Warszawa: Wydawnictwo Naukowe PWN.

Świątkiewicz W. (1992), Religijność w życiu wspótczesnych rodzin, [w:] W. Świątkiewicz (red.), Wartości a style życia rodzin. Socjologiczne badania rodzin miejskich na Górnym Śląsku, Katowice: Uniwersytet Śląski, s. 101-118.

Taranowicz I. (2020), O rodzinie wspótczesnej i jej ksztattowaniu słów kilka, [w:] M. Bieńko, M. Rosochacka-Gmitrzak, E. Wideł (red.), Obrazy życia rodzinnego i intymności. Ksiązka dedykowana Profesor Annie Kwak, Warszawa: Wydawnictwo Uniwersytetu Warszawskiego, s. 31-42.

Tyszka Z. (1974), Socjologia rodziny, Warszawa: Państwowe Wydawnictwo Naukowe.

Tyszka Z. (2001), Stan i przeobrażenia rodzin polskich na przełomie wieków XX i XXI. Niedawna przesztość i teraźniejszość, [w:] Z. Tyszka (red.), Wspótczesne rodziny - ich stan i kierunek przemian, Poznań: Wydawnictwo Naukowe UAM, s. 15-24.

Wrzesień W. (2001), Napięcia pomiędzy pokoleniami w rodzinach bliskich generacji Pokolenia Końca Wieku, [w:] Z. Tyszka (red.), Wspótczesne rodziny - ich stan i kierunek przemian, Poznań: Wydawnictwo Naukowe UAM, s. 243-255.

Żurek A. (2006), Orientacja na matżeństwo młodych singli, Roczniki Socjologii Rodziny, t. 17, s. 27-46.

Żurek A. (2020), O pożytkach ptynących z badań nad rodzina, [w:] M. Bieńko, M. Rosochacka-Gmitrzak, E. Wideł (red.), Obrazy życia rodzinnego i intymności. Ksiażka dedykowana Profesor Annie Kwak, Warszawa: Wydawnictwo Uniwersytetu Warszawskiego, s. 69-78.

\section{MOTYWY ZAŁOŻENIA RODZINY ORAZ WYCHOWANIE DZIECI W OPINII MIESZKAŃCÓW WOJEWÓDZTWA PODKARPACKIEGO I MAŁOPOLSKIEGO}

\section{Streszczenie}

Celem artykułu jest ukazanie motywów posiadania dzieci (założenia rodziny) oraz wartości, jakimi kierują się badani rodzice przy wychowaniu. Starano się w nim także scharakteryzować podobieństwa i różnice w wychowaniu w rodzinie prokreacji i pochodzenia badanych. W artykule przedstawiono wyniki badań jakościowych i ilościowych zrealizowanych wśród mieszkańców województwa podkarpackiego i małopolskiego. Motywy prokreacyjne badanych są związane z postrzeganiem przez nich posiadania dzieci jako „naturalnej kolei rzeczy”, która jest elementem osiągnięcia określonego etapu w życiu. Można dostrzec pewne różnice w aspekcie motywów posiadania dzieci. Starsi rodzice częściej podkreślali, że posiadanie potomstwa było obowiązkiem i oczekiwaniem społecznym, którego spełnienie traktowano jako naturalną konsekwencję zawartego małżeństwa. Młodsi rodzice bardziej akcentowali potrzebę posiadania dzieci w aspekcie dopełnienia ich życia, świadomego wyboru i decyzji oraz samorealizacji. Najważniejszymi wartościami, które starają się przekazać badani rodzice swoim dzieciom, są uczciwość, prawdomówność, szczerość oraz szacunek dla innych. Część badanych wskazywała na różnice w wychowaniu w ich rodzinie pochodzenia i prokreacji.

Słowa kluczowe: rodzina pochodzenia; rodzina prokreacji; wartości; wychowanie. 


\title{
MOTIVES FOR STARTING A FAMILY AND RAISING CHILDREN \\ IN THE OPINION OF THE RESIDENTS OF THE PODKARPACKIE AND MAŁOPOLSKIE VOIVODSHIPS
}

\begin{abstract}
Summary
The aim of the article is to describe the motives of having children (starting a family) and the values that the surveyed parents want to teach their children. Efforts were also made to present the similarities and differences in upbringing in the respondents' family of procreation and origin. The article presents the results of qualitative and quantitative research carried out among the residents of the Podkarpackie and Małopolskie voivodships. The procreative motives of the respondents are related to their perception of having children as a 'natural order of things,' as an element of reaching a certain point in life. There are some differences in the motives for having children. Older parents more often emphasized that having children was a social obligation and expectation, the fulfillment of which was a natural consequence of getting married. Younger parents indicated the need to have children in terms of completing their lives, making conscious choices and decisions, and self-fulfillment. The most important values that parents try to convey to their children are honesty, truthfulness, sincerity and respect for others. Some of the interlocutors pointed to the differences in upbringing in the family of origin and procreation. Some of the interviewees pointed to the differences in upbringing in the family of origin and procreation.
\end{abstract}

Keywords: family of origin; family of procreation; values; upbringing. 